\title{
Hubungan Perilaku Hidup Sehat dengan Prestasi Akademik Mahasiswa di Asrama Universitas Klabat
}

\author{
Metty Wuisang \\ Fakultas Keperawatan, Universitas Klabat, Airmadidi, Minahasa Utara, 95371, Indonesia \\ metty.wuisang@unklab.ac.id
}

\begin{abstract}
A healthy behaviour is a person's actions or activities carried out by someone, both directly and indirectly, to maintain and improve the health condition. Academic achievements are results that have been achieved from learning activities at school or college that are cognitive and usually are determined through measurement and assessment. The purpose of this study is to determine the relationship between healthy living behaviour and academic achievement. This research use analytic observational with the cross sectional approach. The sampling technique is purposive sampling with a sample size of 258 respondents. Data analysis uses the Spearman correlation formula. The conclusion that healthy living behaviour with academic achievement has a significant relationship with $\mathrm{p}=0.011<0,05$. The recommendation for tertiary institutions to improve facilities and regulations that will support the healthy living behaviour of students in improving academic achievements and recommendations for further researchers to change the dependent variable with mental health, quality of life, while the independent variables are blood pressure and economic factors.
\end{abstract}

Keywords: Academic achievement, Healthy behavior, student

\begin{abstract}
Perilaku sehat adalah tindakan seseorang atau kegiatan yang dilakukan oleh seseorang, baik langsung maupun tidak langsung, untuk mempertahankan dan meningkatkan kesehatannya. Prestasi Akademik adalah hasil yang telah dicapai dari kegiatan belajar disekolah atau perguruan tinggi yang bersifat kognitif dan biasanya ditentukan melalui pengukuran dan penilaian. Tujuan penelitian untuk mengetahui hubungan antara perilaku hidup sehat dengan prestasi akademik. Penelitian ini menggunakan jenis penelitian observasional analitik dengan pendekatan cross sectional. Tehnik pengambilan sampel yaitu purposive sampling dengan jumlah sampel 258 responden. Analisis data menggunakan rumus korelasi spearman. Kesimpulan bahwa perilaku hidup sehat dengan prestasi akademik terdapat hubungan yang signifikan dengan nilai $\mathrm{p}=0,011<0,05$. Rekomendasi untuk perguruan tinggi dapat meningkatkan fasilitas dan peraturanperaturan yang akan menunjang perilaku hidup sehat mahasiswa dalam meningkatkan prestasi akademik dan rekomendasi untuk peneliti selanjutnya yaitu merubah variabel dependen dengan kesehatan mental, kualitas hidup sedangkan variabel independent yaitu tekanan darah dan faktor ekonomi
\end{abstract}

Kata kunci: Perilaku hidup sehat Prestasi akademik, Mahasiswa

\section{Pendahuluan}

Derajat kesehatan masyarakat dipengaruhi oleh empat faktor yakni perilaku, lingkungan, pelayanan kesehatan dan keturunan. Faktor perilaku dan faktor lingkungan memegang peran lebih dari $75 \%$ dari kondisi derajat kesehatan masyarakat (KemenKes, 2016). Berbagai program telah dilakukan oleh pemerintah dalam meningkatkan derajat kesehatan masyarakat seperti Program Gizi Anak Sekolah (Kementerian Kesehatan RI, 2017)

Perilaku sehat adalah tindakan seseorang atau kegiatan yang dilakukan oleh seseorang, baik langsung maupun tidak langsung, untuk mempertahankan dan meningkatkan kesehatannya serta mencegah risiko 
penyakit. Secara global kebijakan kesehatan mendorong orang untuk melakukan perilaku hidup sehat dan dapat menyelesaikan masalah kesehatan yang terjadi. Intervensi perubahan perilaku sehat dapat merubah perilaku individu dan komunitas (Glanz, Barbara \& Viswanath, 2015).

Salah satu persoalan yang dihadapi dalam pembangunan SDM di bidang pendidikan yaitu masih rendahnya kualitas gizi. Rendahnya kualitas gizi tersebut salah satunya disumbang oleh faktor asupan makanan yang tidak seimbang. Asupan gizi yang baik dibutuhkan semua orang agar mampu menerima materi pembelajaran yang diberikan dengan baik (Mendikbud, 2017).

Prestasi Akademik adalah hasil yang telah dicapai dari kegiatan belajar disekolah atau perguruan tinggi yang bersifat kognitif dan biasanya ditentukan melalui pengukuran dan penilaian (KBBI, 2019). Prestasi akademik diartikan sebagai penilaian akademik, perilaku dan keterampilan (CDC, 2019). Hasil prestasi akademik mahasiswa diukur dengan indeks prestasi (IP) setiap semester dan Indeks Prestasi Kumulatif (IPK) yang merupakan rata-rata dari nilai setiap mata kuliah yang diakumulasikan kemudian dibagi dengan total SKS yang ditempuh (Nadia, 2017)

Data tahun 2015 National Youth Risk Behavior Survey (YRBS), menunjukkan keberhasilan akademik orang muda di Amerika dipengaruhi oleh perilaku hidup sehat. Berdasarkan data dari Analytical and Capacity Development Partnership, 20\% anak memiliki kebiasaan makan kurang dari tiga kali sehari (Mendikbud, 2017). Berdasarkan penelitian dari Rahmat, Mardia dan Maryam (2015), bahwa terdapat hubungan yang signifikan antara perilaku hidup sehat dengan prestasi belajar. Perilaku hidup sehat berhubungan dengan memperoleh zat gizi yang sesuai dengan kebutuhannya (KemenKes, 2016). Faktorfaktor yang berhubungan dengan perilaku hidup sehat yaitu kebiasaan atau perilaku makan sehat, aktifitas fisik dan pola hidup sedentary (CDC, 2019).

Sejumlah penelitian menyebutkan, anak dengan status kesehatan yang baik berpengaruh baik pula pada penyerapan materi pembelajaran di sekolah. Sayangnya, status gizi sebagian anak-anak Indonesia masih rendah. Pemerintah yang saat itu tengah gencargencarnya melaksanakan program Wajib Belajar 9 Tahun, perlu didukung dengan peningkatan gizi dan kesehatan siswa (Mendikbud, 2017). Kekurangan gizi akan berpengaruh pada produktifitas dan kecerdasan yang dibutuhkan untuk pembangunan bangsa (Cakrawati \& Mustika, 2014).

ProGAS merupakan salah satu bentuk intervensi Kemendikbud untuk menjawab permasalahan banyaknya anak-anak sekolah yang tidak mendapatkan asupan sarapan yang memadai sehingga menggangu konsentrasi belajar. Melalui ProGAS (Program Gizi Anak Sekolah) dari pemerintah pada tahun 2016, didapati bahwa terjadi peningkatan kualitas belajar dan fisik anak (Mendikbud, 2017). Umumnya, mereka berangkat sekolah tanpa sarapan. Penelitian membuktikan bahwa sarapan sangat memengaruhi tingkat konsentrasi belajar dan bekerja. Kurangnya asupan sarapan itu berdampak pada status gizi buruk, konsentrasi belajar menurun, dan ketahanan fisik menurun. Akibatnya kualitas belajar anak menurun. (Mendikbud, 2017).

Konsumsi makanan yang beragam dengan gizi seimbang dan aman dapat memenuhi kecukupan gizi individu untuk tumbuh dan berkembang (Cakrawati \& Mustika, 2014). Makanan yang mengandung unsur gizi sangat diperlukan untuk proses tumbuh kembang. Mengonsumsi makanan yang cukup gizi secara teratur, anak akan tumbuh sehat sehingga mampu mencapai prestasi belajar yang tinggi (Mendikbud, 2017). Makanan yang tidak cukup mengandung zat gizi akan menyebabkan perubahan metabolisme dalam otak, sehingga otak tidak berfungsi normal (Cakrawati \& Mustika, 2014).

Hasil Riset Kesehatan (2007), prevalensi nasional kurang makan buah dan sayur pada penduduk umur $\geq 10$ tahun yaitu 93,5\%, hasil Riskesdas (2013) yaitu 93,6\% dan hasil Riskesdas (2018) yaitu 95,5\% pada penduduk $\geq 5$ tahun. Dietary Guidelines for Americans (2010), merekomendasikan 2 dari 4 grup makanan yang baik untuk dikonsumsi yaitu buah-buahan dan sayuran. Peningkatan konsumsi buah-buahan dalam jangka panjang akan memberikan manfaat untuk masyarakat (CDC, 2011). Konsumsi buah dan sayur merupakan gaya hidup yang akan meningkatkan kesehatan dan mencegah kenaikan berat badan (Ross, Ceballero, Cousins, Tucker \& Ziegler, 2014). Hasil penelitian dari Sepang dan Purnawinadi (2018), menyatakan bahwa ada hubungan yang signifikan antara sarapan pagi dengan prestasi akademik pada mahasiswa Fakultas Keperawatan di Universitas Klabat

Kebutuhan air bagi tubuh dapat dipenuhi dari air minum biasa, jus buah, susu atau minuman ringan. Sumber air terbaik adalah air putih, sedangkan jus atau sari buah memiliki kelebihan mengandung vitamin $\mathrm{C}$ dan A, tetapi seringkali mengandung gula, sedangkan susu kaya akan kalsium. Selain air, beberapa makanan juga dapat menjadi sumber air karena memiliki kadar air yang tinggi. Bahan pangan dengan kandungan air yang tinggi diantaranya sayuran dan buah-buahan (Cakrawati \& Mustika, 2014). 
Menurut penelitian dari Wijayanti (2014) bahwa ada pengaruh pola makan terhadap prestasi belajar. Burrouws, Megan, Amanda, Melinda (2017), mengatakan bahwa ada hubungan antara konsumsi makanan sehat dengan prestasi akademik. Menurut Krissjanson, Inga, John (2010) bahwa ada hubungan yang positif antara perilaku makan sehat dengan prestasi akademik.

Olahraga merupakan bagian dari aktifitas fisik atau dapat dikatakan latihan olahraga (exercise) adalah aktifitas fisik yang terencana, terstruktur, berulang, dan bertujuan untuk memelihara kebugaran fisik. Aktifitas fisik yang teratur pada remaja akan meningkatkan kesehatan. Physical Activity Guidelines for Americans menganjurkan untuk melakukan aktifitas fisik selama 60 menit setiap hari paling kurang 3 kali seminggu (Department of Health and Human Services, 2014).

Perubahan gaya hidup kearah sedentary yaitu gaya hidup yang semakin sedikit melakukan aktifitas fisik berpengaruh terhadap kesehatan. Gaya hidup modern telah meminimalkan aktifitas fisik seseorang (Wilda \& Muhamad, 2013). Proporsi aktifitas fisik tergolong kurang aktif secara umum yaitu 26,1\%. Proporsi penduduk Indonesia dengan perilaku sedentari $\geq 6$ jam perhari 24,1\% (Riskesdas, 2013). Menurut Riskesdas 2018 terjadi peningkatan proporsi dari tahun 2013 yaitu $24,1 \%$ menjadi $33,5 \%$ pada tahun 2018

(Riskesdas, 2018)

Hasil analisis dari Youth Risk Behavior Survey (YRBS) menunjukkan bahwa mahasiswa yang melakukan aktifitas fisik pada tahun 1991 yaitu 41,6\% menjadi 25,4\% tahun 1995 dan tidak mengalami perubahan sampai tahun 2013. Pada tahun 1991 mahasiswa yang melakukan aktifitas fisik sebanyak 4,64x/minggu menjadi 3,64x/minggu pada tahun 1995 dan tidak mengalami perubahan yang signifikan sampai pada tahun 2013 (CDC, 2016).

Hasil penelitian dari Sibley dan Etnier bahwa ada hubungan antara aktifitas fisik dan kognitif pada orang muda. Peneliti lainnya merangkum bahwa ada hubungan antara aktifitas fisik dan prestasi akademik (Departement of health and human services, 2010)

Menurut penelitian dari Kristjánsson, Inga, John (2010), terdapat hubungan antara perilaku hidup sehat dengan prestasi akademik pada remaja. Rahmat, Mardia, Maryam (2015), dalam penelitian mereka bahwa terdapat hubungan antara perilaku hidup sehat dengan prestasi belajar.

Berdasarkan uraian dari latar belakang maka peneliti tertarik untuk melakukan penelitian dengan judul hubungan perilaku hidup sehat dengan prestasi akademik mahasiswa di Universitas Klabat Airmadidi Sulawesi Utara.

\section{Metodologi Penelitian}

Penelitian ini menggunakan jenis penelitian obserfasional analitik dengan pendekatan cross sectional yaitu penelitian yang pengukurannya dilakukan hanya satu kali (Siswanto, Susila, Suyanto, 2014). Analisis data menggunakan rumus frekuensi dan sperman korelasi. Jumlah populasi 550 responden. Tehnik pengambilan sampel yaitu conveniant sampling. Sampel yaitu mahasiswa yang tinggal di asrama Edelweis dan asrama Crystal di Universitas Klabat dengan jumlah 258 responden.

Instrument penelitian, peneliti membuat kuesioner dan melakukan pilot study pada bulan November 2019 dan responden yang diambil berlokasi diasrama Jasmine dan Guest House di Universitas Klabat dan diperoleh nilai Cronbach alfa 0,629. Instrument penelitian yang digunakan pada penelitian ini yaitu kuesioner perilaku hidup sehat dengan nilai Cronbach alfa 0,629. Kuesioner perilaku hidup sehat berjumlah 11 pernyataan. Interpretasi kuessioner yaitu sangat kurang, kurang, cukup, baik dan sangat baik. Prestasi akademik panduan akademik Universitas Klabat yaitu: indeks prestasi 3.87 - 4.00 termasuk, prestasi I (Summa Cum Laude), indeks prestasi 3.67 - 3.86 termasuk prestasi II (Magna Cum Laude), indeks prestasi 3.50 - 3.66 termasuk prestasi III (Cum Laude) dan tidak berprestasi $<3.50$. Analisis data yang digunakan untuk penelitian ini yaitu rumus frekuensi dan presentasi dan rumus Spearman korelasi

Penelitian ini dilakukan di Universitas Klabat dengan pertimbangan peneliti bekerja di Universitas Klabat. Penelitian dimulai pada bulan Agustus 2019 - Juli 2020 diawali dengan perizinan tempat penelitian, persiapan penelitian, pelaksanaan penelitian di asrama Edelweis dan asrama Crystal Universitas Klabat dengan mengisi kuetioner perilaku hidup sehat dan prestasi akademik mahasiswa, pengelolaan hasil, dan pembuatan laporan penelitian. Etika penelitian sebagai suatu perangkat aturan dan prinsip-prinsip etik yang disepakati bersama menyangkut hubungan antara peneliti disatu sisi dan semua yang terlibat dalam penelitian atau partisipan penelitian di sisi yang lain. Etika penelitian yang digunakan dalam penelitian ini yaitu kejujuran, objektifitas, integritas, ketelitian, keterbukaan, penghargaan terhadap hak atas kekayaan intelektual, penghargaan terhadap kerahasiaan (Siswanto dkk, 2014). 


\section{Hasil}

Gambaran perilaku hidup sehat, gambaran prestasi akademik dan hubungan antara perilaku hidup sehat dengan prestasi akademik di Universitas Klabat

Tabel 1. Gambaran perilaku hidup sehat mahasiswa di Universitas Klabat

\begin{tabular}{lrc}
\hline Perilaku hidup sehat & \multicolumn{1}{c}{$\mathbf{N}$} & Persen (\%) \\
\hline Kurang & 28 & 10,9 \\
Cukup & 189 & 73,3 \\
Baik & 41 & 15,9 \\
Total & 258 & 100,0 \\
\hline
\end{tabular}

Tabel 1 menunjukkan gambaran perilaku hidup sehat mahasiswa di Universitas Klabat yaitu perilaku hidup cukup sehat 189 responden $(73,3 \%)$, perilaku hidup sehat dengan kategori baik ada 41 responden $(15,9 \%)$ dan perilaku hidup sehat yang kurang baik ada 28 responden $(10,9 \%)$

Tabel 2. Gambaran prestasi akademik mahasiswa di Universitas Klabat

\begin{tabular}{lrc}
\hline Prestasi Akademik & N & Persen (\%) \\
\hline Tidak berprestasi & 153 & 59,3 \\
Prestasi 3 (cum laude) & 41 & 15,9 \\
Prestasi 2 (magna cum laude) & 46 & 17,8 \\
Prestasi 1 (summa cum laude) & 18 & 7,0 \\
Total & 258 & 100,0 \\
\hline
\end{tabular}

Tabel 2 menunjukkan gambaran mahasiswa yang tidak berprestasi 153 responden $(59,3 \%)$, mahasiswa dengan prestasi 2 ada 46 responden $(17,8 \%)$, mahasiswa dengan prestasi 3 ada 41 responden $(15,9 \%)$ dan mahasiswa dengan prestasi 1 ada 18 responden $(7,0 \%)$.

Tabel 3. Hubungan perilaku hidup sehat dengan prestasi akademik mahasiswa di Universitas Klabat

\begin{tabular}{lccc}
\hline Variabel & \multicolumn{2}{l}{ Perilaku hidup sehat } & Interpretasi \\
\hline & $\mathrm{p}$ & $\mathrm{r}$ & \\
\cline { 2 - 3 } & & & \\
$\begin{array}{l}\text { Prestasi } \\
\text { akademik }\end{array}$ & 0,011 & 0,15 & Signifikan \\
\hline
\end{tabular}

Tabel 3 menunjukkan bahwa terdapat hubungan yang signifikan antara perilaku hidup sehat dengan prestasi akademik dengan nilai $\mathrm{p}=0,011<0,05$ dan nilai $\mathrm{r}=$ 0,15 yang berarti memiliki keeratan hubungan yang sangat lemah dengan arah hubungan positif yang artinya jika perilaku hidup sehat baik maka prestasi akademik akan meningkat atau sebaliknya

\section{Pembahasan}

Hasil penelitian berdasarkan tabel 1 terdapat perilaku cukup sehat yaitu 189 responden $(73,3 \%)$. Sejalan dengan hasil penelitian dari Heidari, Marzieh, Mansureh, Mina (2017) bahwa terdapat 61,01\% perilaku cukup sehat pada mahasiswa keperawatan. Faktor yang mempengaruhi derajat kesehatan yaitu lingkungan, pelayanan kesehatan, genetik dan perilaku. Faktor perilaku merupakan faktor yang paling sulit dikendalikan (Dewi, 2017) Perilaku sehat untuk jangka panjang dipengaruhi oleh kepatuhan pada perilaku itu sendiri ( Middleton, Stephen dan Michal, 2013).

Pemerintah Indonesia mempunyai program yaitu ProGAS (Program Gizi Anak Sekolah) yang berfokus pada perubahan perilaku hidup sehat anak Indonesia (Kementerian Pendidikan dan Kebudayaan, 2017). Universitas Klabat juga memfasilitasi mahasiswa yang tinggal diasrama dalam bentuk menyediakan dinning room agar mahasiswa mendapat makanan yang sehat, juga fasilitas olah raga dalam menunjang kesehatan mahasiswa dan juga kurikulum pembelajaran yang berhubungan dengan kesehatan

Hasil penelitian berdasarkan tabel 2 terdapat mahasiswa yang tidak berprestasi 153 responden (59,3\%). Mahasiswa yang tidak berprestasi memiliki nilai indeks prestasi $<3,5$. Berbeda dengan hasil penelitian dari Sihombing dan Ed (2018) bahwa terdapat $87,7 \%$ mahasiswa dengan prestasi sangat memuaskan. Prestasi Akademik adalah hasil yang telah dicapai dari kegiatan belajar disekolah atau perguruan tinggi yang bersifat kognitif dan biasanya ditentukan melalui pengukuran dan penilaian (KBBI, 2019). Hasil prestasi akademik mahasiswa diukur dengan indeks prestasi (IP) setiap semester dan Indeks Prestasi Kumulatif (IPK) yang merupakan rata-rata dari nilai setiap mata kuliah yang diakumulasikan kemudian dibagi dengan total SKS yang ditempuh (Nadia, 2017)

Berdasarkan hasil penelitian dari Retnowati dan Fatchan (2016) bahwa prestasi akademik dipengaruhi oleh faktor internal dan eksternal mahasiswa Faktor yang berasal dari dalam diri sendiri antara lain: kesehatan, intelegensi, minat dan motivasi serta cara belajar dan juga faktor luar diri (eksternal), antara lain: 
keluarga, sekolah, masyarakat dan lingkungan sekitar (Endriani, 2011)

Hasil penelitian dari tabel 3 yaitu terdapat hubungan yang signifikan antara perilaku hidup sehat dengan prestasi akademik dengan nilai $\mathrm{p}=0,011$. Menurut penelitian dari Kristjánsson, Inga, John (2010), terdapat hubungan antara perilaku hidup sehat dengan prestasi akademik pada remaja. Rahmat, Mardia, Maryam (2015), dalam penelitian mereka bahwa terdapat hubungan antara perilaku hidup sehat dengan prestasi belajar. Sejalan dengan hasil penelitian dari Heidari, Marzieh, Mansureh, Mina (2017) bahwa terdapat hubungan yang signifikan antara perilaku hidup sehat dengan prestasi akademik.

Nutrisi yang baik akan meningkatkan daya ingat sehingga dapat belajar dengan baik. Ada berbagai jenis makanan yang baik untuk otak, seperti blueberry untuk meningkatkan memori, kacang memiliki segala macam hal yang meningkatkan otak seperti kacang kenari sangat bagus untuk menjaga aliran darah dan menyehatkan otak (Crockett, 2014).

Aktivitas fisik dapat berdampak pada kinerja akademik melalui berbagai mekanisme fisiologis, kognitif, emosional, dan pembelajaran langsung dan tidak langsung (CDC, 2010). Fungsi kognitif dasar terkait dengan perhatian dan daya ingat memfasilitasi pembelajaran, dan fungsi-fungsi ini ditingkatkan oleh aktivitas fisik (Kohl \& Heather, 2013).

\section{Kesimpulan}

Gambaran perilaku hidup sehat mahasiswa di Universitas Klabat yaitu perilaku hidup cukup sehat 189 responden $(73,3 \%)$, perilaku hidup sehat dengan kategori baik ada 41 responden $(15,9 \%)$ dan perilaku hidup sehat yang kurang baik ada 28 responden $(10,9 \%)$. Gambaran mahasiswa yang tidak berprestasi 153 responden $(59,3 \%)$, mahasiswa dengan prestasi 2 ada 46 responden $(17,8 \%)$, mahasiswa dengan prestasi 3 ada 41 responden $(15,9 \%)$ dan mahasiswa dengan prestasi 1 ada 18 responden $(7,0 \%)$. Terdapat hubungan yang signifikan antara perilaku hidup sehat dengan prestasi akademik nilai $\mathrm{p}=0,011$. Rekomendasi perguruan tinggi dapat meningkatkan fasilitas seperti fasilitas tempat untuk melakukan senam (gym) dan alat alat penunjang untuk senam, kolam renang, café sehat dan peraturan-peraturan yang akan menunjang perilaku hidup sehat mahasiswa dalam meningkatkan prestasi akademik

\section{Daftar Pustaka}

Burrouws T. L., Megan C.L, Amanda J.P, Melinda J.H. (2017). Association between dietary intake and Academic achievement in collage students. Journal Healthcare

Cakrawati, D., \& N.H. Mustika. (2014). Bahan Pangan, Gizi, dan Kesehatan. Alphabet Bandung

CDC. (2010). The Association Between School-Based Physical Activity, Including Physical Education, and Academic Performance. U.S. Department of Health and Human Services.

CDC. (2011). The CDC Guide to Strategies to Increase the Consumption of Fruits and Vegetables. U.S. Department of Health and Human Services.

CDC. (2019, 25 Mei). Adolescent and school health. Diakses dari http://www.cdc.gov

CDC. (2019, 24 Mei). Health and academic achievement. Diakses dari. http://www.cdc.gov.

Crockett K.A. (2014). Nutrition for Achievement in Sports and Academics. Vestal Creative Services

Department of Health and Human Services. (2014). Physical Education Profiles, 2012. CDC

Dewi M., P., P. (2017). Keperawatan transcultural: pengetahuan dan praktek berdasarkan budaya. Pustaka Baru Press

Endriani A. (2011, 4 Maret). Faktor yang Mempengaruhi prestasi belajar. https://bit.ly/3qLgRIj

Glanz K., Barbara K.R., K Viswanath. (2015, 18 April). Health behaviors: theory, researchand practice. Diakses darihttps://bit.ly/2LgEAQs

Heidari M, Marzieh B, B., Mansurah G., B, Mina S. (2017). Relationship of Lifestyle With Academic Achievement in Nursing Students. J Clin Diagn Res

Kementerian Kesehatan RI. (2007). Hasil Riset Kesehatan Dasar. Kementerian Kesehatan RI

Kementerian Kesehatan RI. (2013). Hasil Riset Kesehatan Dasar. Kementerian Kesehatan RI

Kementerian Kesehatan RI. (2016). Gerakan masyarakat hidup sehat. Kementerian Kesehatan RI

Kementerian Kesehatan RI. (2016). Pedoman Indonesia sehat dengan pendekatan keluarga. Kementerian Kesehatan RI

Kementerian Pendidikan dan Kebudayaan RI. (2017). Gizi untuk prestasi. Kementerian Pendidikan dan Kebudayaan RI.

Kementerian Kesehatan RI. (2018). Hasil Riset Kesehatan Dasar. Kementerian Kesehatan RI

Kohl H. W \& Heather D. (2013). Educating the student body: taking physical activity and physical education to school. National Academy of Sciences 
Kristjánsson A. L., Inga D.S., John P.A. (2010). Perilaku hidup sehat pada remaja; kebiasaan makan, aktifitas fisik, IMT da n harga diri. Journal Health Education and Behavior

KBBI. (2019). Prestasi akademik. Diakses 18 April 2019. https://kbbi.web.id/prestasi

Nadia. (2017, 13 Mei). Faktor yang mempengaruhi prestasi mahasiswa. https://bit.ly/39VsJle

Rahmat A., Mardia B.S., Maryam R. (2015). Perilaku hidup sehat dan prestasi Belajar siswa SD. Jurnal Ilmiah Psikologi.

Retnowati D., R, Fatchan I., K. (2016). Prestasi akademik dan motivasi berprestasi mahasiswa S1 Pendidikan Geografi Universitas Malang. Jurnal Pendidikan

Ross A.C, B Ceballero, R..J Cousins, K.L Tucker \& T.L Ziegler. (2014). Modern nutrition in health and desease. Lippincott Williams \& Wilkins, a Wolters Kluwer business

Siswanto S.A.P., Susila., Suyanto. (2014). Metodologi penelitian kesehatan dan kedokteran. Bursa Ilmu Yokyakarta

Sepang L. G., \& Purnawinadi I. G. (2018). Kebiasaan sarapan dengan prestasi akademik dikalangan mahasiswa Fakultas Keperawatan Universitas Klabat. Proceeding $6^{\text {th }} I S C$

Sihombing R., M, Ed R., P. (2018). Hubungan pola perilaku hidup sehatdengan prestasi akademik mahasiswa keperawatan. Jurnal Nursing Current

Wijayanti H. (2014). Pengaruh pola makan terhadap prestasi belajar siswa bidang keahlian tata boga di SMK Negeri 3 Pati tahun pelajaran 20102011. Jurnal Teknoboga

Wilda, W. \& Muhamad, S.R. (2013). Gizi untuk aktifitas fisik dan kebugaran. Sukabina Press. Padang 